\title{
Studies on Bioefficacy of Aqueous Plant Extracts against Pectobacterium carotovorum causing Black Leg and Soft Rot of Potato
}

\author{
G. Biswal* and N. K. Dhal \\ Department of Plant Pathology, College of Agriculture, Odisha University of Agriculture and \\ Technology, India \\ *Corresponding author
}

\section{A B S T R A C T}

\section{Keywords}

Bioefficacy, Aqueous plant extracts,

Antibacterial activity, Black leg and Soft rot

\section{Article Info}

Accepted: 26 September 2020 Available Online: 10 October 2020
Studies were conducted in the Department of Plant Pathology, Odisha University of Agriculture and Technology, Bhubaneswar following inhibition zone technique to test the bio-efficacy of plant extracts in vitro against Pectobacterium carotovorum causing preemergence and post-emergence rotting, black leg in field soft rot in storage in potato. The seeds of locally grown trees, spices and weeds are used in the tests. These were Terminalia chhebula (Chhebulic myrobalan),T. belerica (Beleric myrobalan), Emblica officinalis (Indian goose berry), (Azadirachata indica (Neem), (Greater cardamom), Rauvolfia serpentina (Snake root), Coriandrum sativum (Dhania), Cuminum cyminum (Cumin), Nigella sativa (Black cumin), Foeniculum vulgare (Fennel), Piper nigrum (Black pepper), Cassia fistula (Indian laburn), Cassia tora (Senna tora). It was observed that R.serpentina exhibited maximum size of inhibition zone .13 .53 followed by A.subulatum (11.33) against the test bacterial species. The inhibition zone was found to be $10.0 \mathrm{~mm}$ in seed extracts of T.chebula and dried flower extracts of Syzygium caryophyllus while $9.30 \mathrm{~mm}$ in F.vulgare, 8.68 in C.cyminum and $8.03 \mathrm{~mm}$ in N.sativa. There was no statistically significant difference in inhibiting activity between $A$. aromaticum $(7.97 \mathrm{~mm})$ and A.indica $(7.92 \mathrm{~mm})$. The inhibition was same $(7.01 \mathrm{~mm})$ in both T.bellirica and C.viscosa. In P.nigrum, C.fistula and C.tora also expressed same inhibiting activity $(6.95 \mathrm{~mm})$. Minimum inhibition zone was observed in E.officinallis $(6.68 \mathrm{~mm})$.

\section{Introduction}

Potato (Solanum tuberosum) is considered as the most potential and nutritionally superior crop for fighting against hunger in both developing and under developed countries. Globally potato diseases mainly revealed the presence of 30 fungal, 7 bacterial and 36 viral diseases causing loss individually or collectively to the crop. The blackleg and soft rot cased by Pectobacterium carotovorum is an important disease of potato of the country, damaging the crop during pre and post emergence stage, growing period, harvest and post harvest operations like storage, transport and also at consumer level. The disease was found to be severe in immaturely harvested and peeled tubers while transported under poorly ventilated condition and under normal package of practices, i.e. $4 \%$ in north western 
plains and $10 \%$ in eastern and peninsular India and 4-8\% in hills (Somani and Shekhawat, 1990). In different locations of Odisha the black leg incidence varied from 1.35 to $4.36 \%$ in growing period and 4.19 to $6.47 \%$ of soft rot of tubers during harvest (Biswal and Dhal, 2013). The use of plant products have remarkable effects in plant disease management (Cowan, 1990 and Newman et al., 2000). The use organic farming is now gaining popularity. Different parts of many plants have antimicrobial properties. In this context the seeds of some commonly grown trees, weeds, medicinal plants and spices were tested against $P$. carotovorum causing black leg and soft rot of potato.

The seeds used in the studies were Terminalia chhebula (Chhebulic myrobalan), T. belerica (Beleric myrobalan), Emblica officinalis (Indian goose berry), (Azadirachata indica (Neem), (Greater cardamom), Rauvolfia sepentina (Snake root), Coriandrum sativum (Dhania), Cuminum cyminum (Cumin), Nigella sativa (Black cumin), Foeniculum vulgare (Fennel), Piper nigrum (Black pepper), Cassia fistula (Indian laburn), Cassia tora (Senna tora). Hence the present investigation comprising in vitro testing of abovementioned seed extracts was conducted in the Department of Plant Pathology, Odisha University of Agriculture and Technology, Bhubaneswar following inhibition zone technique (Valgas et al., 2007).The study was undertaken keeping in view of use such extracts as tuber treatment at planting time, basal drenching in field and also tuber treatment in storage after harvest.

\section{Materials and Methods}

The clean and healthy seeds of fifteen plants,i.e. Terminalia chhebula (Chhebulic myrobalan), T. belerica (Beleric myrobalan), Emblica officinalis (Indian goose berry),
(Azadirachata indica (Neem), (Greater cardamom), Rauvolfia sepentina (Snake root), Coriandrum sativum (Dhania), Cuminum cyminum (Cumin), Nigella sativa (Black cumin), Foeniculum vulgare (Fennel), Piper nigrum (Black pepper), Cassia fistula (Indian laburn), Cassia tora (Senna tora) as well as dry flower buds of Syzygium aromaticum (cloves) were collected (Table 1). These were washed several times in sterilized water and air dried. Fifty grams from selected seeds and dried flower buds along with $50 \mathrm{ml}$ of double distilled water were taken grinded with the help of pestal and mortar to a fine pulp. The pulp was filtered through two layers of muslin cloth and gently pressed to get maximum filterate.

The filterate from each plant part was collected and kept separately in different sterile specimen tubes and centrifused at 1500 rpm for 15 minutes. The supernatant liquid was drawn carefully into a $5 \mathrm{ml}$ syringe and then passed through membrane filter of $0.45 \mathrm{~nm}$ size to sterilize the extract. The filter sterilized extract of each part collected in sterilized specimen tube with screw cap and stored in deep freeze maintained at $-20^{\circ} \mathrm{C}$. The extracts were evaluated in vitro following the inhibition zone technique.

In this technique, two drops of bacterial suspension of each test bacterium was transferred on to the petriplate containing NSA medium and spreaded over the surface of the medium with the help of a sterilized glass spreader. Three sets of Hi-media discs $(5 \mathrm{~mm})$, soaked for one minute in each plant extracts were placed on the media surface of each petriplate at the equidistance from the centre. In each set four numbers of discs were used to hold sufficient quantity of the plant extract. Two sets of petridishes were used for testing each plant extract petriplates were incubated at $27 \pm 1^{\circ} \mathrm{C}$ for 24 hours in a BOD incubator. After the incubation period, the 
petriplates were examined for development of inhibition zone around the discs. The diameters of each zone of inhibition was measured and recorded and analysed statistically to assess the antimicrobial properties of plant extracts against each test bacterium (Gomez and Gomez, 1984). In control the paper discs were soaked in sterilized water.

\section{Results and Discussion}

All the selected aqueous plant extracts exhibited various levels of antibacterial activity against P.carotovorum, the test bacterial species (Table 2). The aqueous seed extracts of $R$. serpentina exhibited highest length of inhibition zone. 13.53 (Fig.1) followed by A.subulatum $(11.33 \mathrm{~mm})$ against the test bacterial species. The inhibition zone was found to be $10.0 \mathrm{~mm}$ in seed extracts of T.chebula while $9.30 \mathrm{~mm}$ in F.vulgare, 8.68 in C.cyminum and $8.03 \mathrm{~mm}$ in N.sativa.

There was no significant difference in antibacterial activity between $A$ aromaticum $(7.97 \mathrm{~mm})$ and A.indica $(7.92 \mathrm{~mm})$. The antibacterial activity was as par as in T.bellirica $(7.00 \mathrm{~mm})$ and C.viscosa $(7.01 \mathrm{~mm})$ while in $C$. sativum it was $7.28 \mathrm{~mm}$. The seed extracts of P.nigrum, C.fistula and C.tora expressed same activity $(6.95 \mathrm{~mm})$. Minimum inhibition zone (Fig.2) was observed in E.officinallis $(6.68 \mathrm{~mm})$. No zone of inhibition of bacterial growth was observed in control. The inhibition zone in aqueous seed extracts ranged from $6.68 \mathrm{~mm}$ to $13.53 \mathrm{~mm}$ (Fig.3).

Several workers reported on the antimicrobial properties of above mentioned seed extracts and also the different parts of respective plants. Negi et al (2014) recorded the antibacterial activities of $R$ serpentine. In $A$ subulatum bio-chemical and biological activities had been studied by Bisht et al., (2011).
Antibacterial activity of black myrobalan (Terminalia chebula) against Helicobacter pylori had been studied and reported (Malekzadeh et al., 2001).Rathre and Qureshi (2016) compiled the traditional uses and pharmacological behaviour of F.vulgare. Lacobellis et al., 2005 reported the antibacterial activity of $C$. cyminum. Parihar et al (2012) detected the antioxidant immunomodulatory and antimicrobial activity of Amomum aromaticum against Klebsiella pneumonia. Dharmaratne etal (2018) reported antibacterial properties of T.bellirica against selected multi drug resistant bacteria.

Datta and Kundabala, (2013) studied the antimicrobial efficacy of endodontic irrigants from Azadirachta indica. Saeed and Tariq (2007) reported the antimicrobial activities of Emblica officinalis and Coriandrum sativum against gram positive bacteria and Candida albicans. Kalane et al., (2011) studied the antimicrobial activity of Cassia tora. Zou et al., (2015) worked on antibacterial mechanism and activities of black pepper chloform extract.

The antibacterial activity of black myrobalan (Terminalia chebula) against Helicobacter pylori had been reported (Malekzadeh et al 2001). Mnif and Aifa (2015) compiled the beneficial effect of cumin (Cuminum cyminum L.) from traditional uses to potential biomedical applications. Raja Ratna Reddy et $a l$. , (2016) recorded the antimicrobial activity of Azadirachta indica (neem) leaf, bark and seed extracts. And Nunez and Aquino (2012) recorded anti microbial property of $S$ aromaticum.

The inhibition zone in aqueous seed extracts ranged from $6.68 \mathrm{~mm}$ to $13.53 \mathrm{~mm}$ (Fig.3). It was indicated all the seeds used in the test had antibacterial properties against $P$. carotovorum. 
Table.1 Scientific name, common name, family and traditional uses of test plants

\begin{tabular}{|c|c|c|c|c|c|}
\hline Sl.no & category & Scientific Name & $\begin{array}{l}\text { Common } \\
\text { name } \\
\text { (English) }\end{array}$ & Family & Traditional uses \\
\hline 1 & Medicinal tree & $\begin{array}{l}\text { Terminalia } \\
\text { chebula }\end{array}$ & $\begin{array}{l}\text { Chebulic } \\
\text { myrobalan }\end{array}$ & Combretaceae & $\begin{array}{l}\text { It is used in treatment of constipations, colic pain, kidney dysfunction, eye diseases and } \\
\text { sore throat,(https;//vikaspedia.in/agriculture,Basa et al,2017) }\end{array}$ \\
\hline 2 & Medicinal tree & T.belerica & $\begin{array}{l}\text { Belericic } \\
\text { myrobalan }\end{array}$ & Combretaceae & $\begin{array}{l}\text { It is used in treatment of constipations, colic pain, kidney dysfunction, eye diseases and } \\
\text { sore throat. Seeds are edible(Kumar et al,2018) }\end{array}$ \\
\hline 3 & Medicinal tree & Emblica officinals & Aonla & Euphorbiaceae & $\begin{array}{l}\text { Used in treatment of constipations, colic pain, kidney dysfunction, eye diseases and sore } \\
\text { throat(.Sharma et al,2003) }\end{array}$ \\
\hline 4 & Spices & $\begin{array}{l}\text { Amomum } \\
\text { subulatum }\end{array}$ & $\begin{array}{l}\text { Greater } \\
\text { cardamom }\end{array}$ & Zingiberaceae & It is antimicrobial cardiac stimulant, carminative, diuretic stomachi (Bisht et al,2011) \\
\hline 5 & Medicinal plant & $\begin{array}{l}\text { Rauvolfia } \\
\text { serpentina }\end{array}$ & Snake root & Apocynaceae & $\begin{array}{l}\text { Used for various aliments such as snakebites, insomnia,hypertension and insanity (Singh et } \\
a l, 2017 \text {.Negi et al,2014) }\end{array}$ \\
\hline 6 & Weed plant & Cleome viscosa & $\begin{array}{l}\text { Wild } \\
\text { mustard }\end{array}$ & Cleomaceae & Used against fever, diarrhea, cardiac stimulant and carminative (Perumal Samy et al.,1999) \\
\hline 7 & Spices & $\begin{array}{l}\text { Coriandrum } \\
\text { sativum }\end{array}$ & Coriander & Apiaceae & $\begin{array}{l}\text { Seeds are antidiabetic,anti-inflammatory and lowers cholesterol. It is used as } \\
\text { diuretic,carminative,stimulant,nagelsteic,antihelmtic,hypoglycaemic (Waheed et al,2006) }\end{array}$ \\
\hline 8 & Spices & $\begin{array}{l}\text { Cuminum } \\
\text { cyminum }\end{array}$ & Cumin & Apiaceae & $\begin{array}{l}\text { Seeds used as food additive, popular spice, flavouring agent in many cuisines. It is used } \\
\text { against hypolipidemica, cancer and diabetes(Mnif and Aifa ,2015) }\end{array}$ \\
\hline 9 & Tree & $\begin{array}{l}\text { Azadirachata } \\
\text { indica }\end{array}$ & Neem & Meliaceae & $\begin{array}{l}\text { Anti oxidant, antimalarial, antimutagenic, anticarcinogenic, anti inflammatory, } \\
\text { antihyperglycaemic, antiulcer and antidiabetic purposes (Venugopalan and Visweswaran, } \\
\text { 2013) }\end{array}$ \\
\hline 10 & Shade tree & Cassia tora & Senna tora & Fabaceae & Used against leprosy, bronchitis and cardiac disorders (Maity et al,1998) \\
\hline 11 & Spices & Nigella sativa & Black cumin & Ranunrulaceae & $\begin{array}{l}\text { Commonly used for culinary and medicinal purposes as a remedy of hypertension and } \\
\text { diabetes and as hypoglycemic, anti-inflammatory, antiulcer and broncho dilator (Bereksi et } \\
\text { al., 2018) }\end{array}$ \\
\hline 12 & Spices & $\begin{array}{l}\text { Foeniculum } \\
\text { vulgare }\end{array}$ & Fennel & Apiaceae & $\begin{array}{l}\text { Fennel seeds helps in digestion, prevents acne, mouth freshner,,beats bad breath(Al-Timimi } \\
\text {,2019) }\end{array}$ \\
\hline 13 & Spices & Piper nigrum & $\begin{array}{l}\text { Black } \\
\text { pepper }\end{array}$ & Piperaceae & $\begin{array}{l}\text { It is used as spice. It exhibit sedating, detoxification, hypotensive and anticancer activities. } \\
\text { (Butt et al., 2012) }\end{array}$ \\
\hline 14 & Spices & $\begin{array}{l}\text { Amomum } \\
\text { aromaticum }\end{array}$ & $\begin{array}{l}\text { Aromatic } \\
\text { cardamom }\end{array}$ & Zingiberaceae & $\begin{array}{l}\text { Seeds are used to make a gangle or mouth wash to treat toothache,gingivitis and } \\
\text { paradontosis. Seeds are antibacterial and use against stomachic, alleviate dyspepsia, } \\
\text { fatulance, colic, vomiting, diarrhoea, cough (Basak et al., 2017) }\end{array}$ \\
\hline 15 & Shade tree & Cassia fistula & $\begin{array}{l}\text { Indian } \\
\text { laburnum }\end{array}$ & Fabaceae & $\begin{array}{l}\text { The bark is used in treatment of inflammatory swellings and as a cleaning agent for ulcers } \\
\text { and wounds. It is believed to decrease purulent discharge and act as local antiseptic. The } \\
\text { seeds are are antibilious, asperitif, carminative and laxative (Ajaya Kumar, et al., 2017) }\end{array}$ \\
\hline 16 & Spices & $\begin{array}{l}\text { Syzygium } \\
\text { aromaticum }\end{array}$ & Cloves & Myrtaceae & $\begin{array}{l}\text { The dried flower buds contain high antioxidants, regulate blood sugar, reduce stomach } \\
\text { ulcers,may promote bone health (Chaieb et al,2007) }\end{array}$ \\
\hline
\end{tabular}


Table.2 Inhibition of growth of bacterial species by aqueous seed extract under in vitro condition

\begin{tabular}{|l|l|l|l|c|}
\hline Sl.No & Scientific Name & $\begin{array}{l}\text { Common name } \\
\text { (English) }\end{array}$ & $\begin{array}{c}\text { Local name } \\
\text { Done iam } \text { mm }\end{array}$ \\
\hline $\mathbf{1}$ & Terminalia chebula & Chebulic myrobalan & Harida & $10.00(3.24)$ \\
\hline $\mathbf{2}$ & T.myrobalan & Belericic myrobalan & Bahada & $7.00(2.74)$ \\
\hline $\mathbf{3}$ & Emblica officinals & Aonla & Aonla & $6.68(2.68)$ \\
\hline $\mathbf{4}$ & Amomum subulatum & Greater cardamom & Bada alaicha & $11.33(3.44)$ \\
\hline $\mathbf{5}$ & Rauvolfia serpentine & Snake root & Patal garuda & $13.63(3.72)$ \\
\hline $\mathbf{6}$ & Cleome viscosa & Wild mustard & Banasorisha & $7.01(2.74)$ \\
\hline $\mathbf{7}$ & Coriandrum satium & Coriander & Dhania & $7.28(2.79)$ \\
\hline $\mathbf{8}$ & Cuminum cyminum & Cumin & Jeera & $8.68(3.03)$ \\
\hline $\mathbf{9}$ & Azadirachata indica & Neem & Nimba & $7.92(2.86)$ \\
\hline $\mathbf{1 0}$ & Cassia tora & Senna tora & Chhota chakunda & $6.95(2.73)$ \\
\hline $\mathbf{1 1}$ & Nigella sativa & Black cumin & Kala jeera & $8.03(2.92)$ \\
\hline $\mathbf{1 2}$ & Foeniculum vulgare & Fennel & Panamadhuri & $9.30(3.13)$ \\
\hline $\mathbf{1 3}$ & Piper nigrum & Black pepper & Golamaricha & $6.95(2.73)$ \\
\hline $\mathbf{1 4}$ & Amomum aromaticum & Aromatic cardamom & Alaicha & $7.97(2.91)$ \\
\hline $\mathbf{1 5}$ & Cassia fistula & Indian laburnum & Sunari & $6.95(2.73)$ \\
\hline $\mathbf{1 6}$ & Syzygium caryophyllus & Clove & Labanga & $10.00(0.71)$ \\
\hline $\mathbf{1 7}$ & Sterilized & & & $0.00(0.71)$ \\
\hline & Water & SE(m) \pm & & \\
\hline & CD(P=0.05) & & \\
\hline
\end{tabular}

Figures in parentheses are in $\sqrt{\mathrm{x}}+0.5$ transformed values 
Fig.1 Inhibition zone observed in $R$ serpentina, Fig.2-Inhibition zone observed in E.officinallis
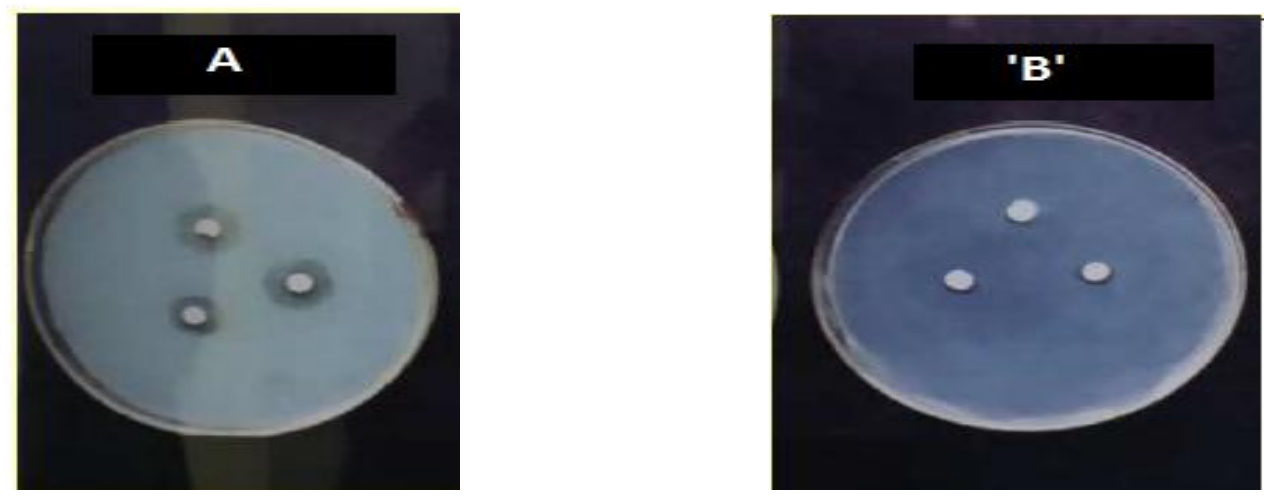

Fig.3 Histogram showing zone of inhibition (in $\mathrm{mm}$ ) in different aqueus extracts against the test pathogen

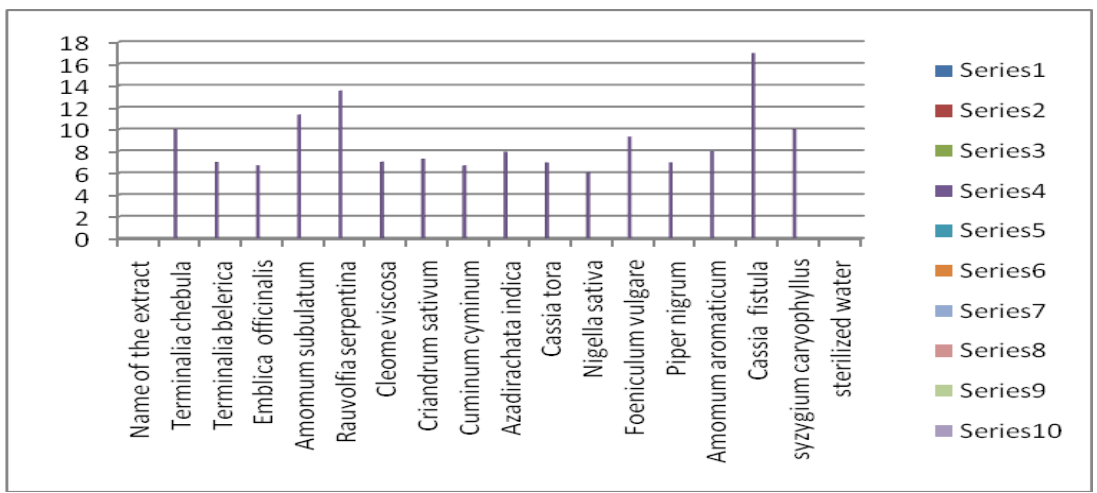

The antibacterial property of $T$. chhebula (Chhebulic myrobalan), T. belerica (Beleric myrobalan), E. officinalis (Indian goose berry), (A. subulatum), (Greater cardamom), $R$. sepentina (Snake root), $C$. sativum (Dhania), C. cyminum (Cumin), N. sativa (Black cumin), Foeniculum vulgare (Fennel), Piper nigrum (Black pepper), A. aromaticum (aromatic cardamom) against $P$. carotovorum are reported to be new in India. Use of such extracts as tuber treatment at planting time, basal drenching in field and also tuber treatment in storage after harvest are to be tested.

\section{References}

Ajay Kumar K, Satis S, Sayeed I, Hedge K. (2017). Therapteuic uses of Cassia fistula: Review. Int. J. Pharma. Chem. Res. 31 (1):38-43

Ali BH, Blunden G. (2003). Pharmacological and toxicological properties of Nigella sativa. Phytother. Res. 17(4):299-305

Al-Timimi LN (2019). Antibacterial and anticancer activities of Fenugreek seed extract. Asian Pacific J. Cancer Prevent. 209(12):3771-3776

Ardha Jyoti, K. And Suba Rao, B. (2010). In vitro antibacterial activity of Cleome viscosa. Pharma Sci.Monitor Reptr. 1(2):71-78

Basa SJ, Jayashankar Reddy V, Koshma M, Hanumanthu G, Dadakhalandar S. (2017). A review on Terminalia chebula. Inter. J. Pharmaco. Res. 7(10):187-191

Basak, S., Sharma, G.C., Rangan, L.2010. Ethnomedical uses of Zingiberaceous 
plants of North East India. $J$. Ethonopharmaco. 132(1):286-296

Bereksi MS, Hassaine H, Bekhechi C, Abdelouahid DE.(2018).Evaluation of antibacterial activity of some medicinal plant extracts commonly used in Algerian Traditional Medicine against some Pathogenic Bacteria. Pharmacogon. J. 10(3): 507-512.

Bisht VK, Negi JS, Bhandari AK, Sunderiyal RC. (2011). Ammomum subulatum Roxb: Traditional biochemical and biological activities. African J. Agricultu. Res. 6(24): 5386-5390.

Biswal G and Dhal, NK (2013). Survey on natural occurrence of diseases in potato at various locations of Odisha. Internat. J. Plant Protect. 6(1):188-191.

Butt MS, Pasha I, Sultan MT, Randhwa MA, Saeed F, Ahmed W.(2012). Black pepper and health claims: a comprehensive treaties. Crit. Rev. Food. Sci.53:875-886

Chaieb K. Hajlaoui H, Znantarr T, AmeBenKhala, N, Rouabhai 2007. The chemical composition and biological activity of clove essential oil. phytotherapy Res. 21(6):501-506.

Cowan MM (1999) Plant products as microbial agents. Clinical Microbial Reviews. 2(4): 63-78.

Dharmaratne MPJ, Manoraj A, Thevanesam V, Ekanayake A, Kumar NS, Liyanapathirana V, Abeyratne E and Bandara BR. (2018). Terminalia bellirica fruit extracts: in vitro antibacterial activity against selected multidrug resistant bacteria, radical scavaenging activity and cytotoxicity study on BHK-21 cells. BMC Complementary and Alternative Medicine 18(1): 1-12.

Dutta A, Kundabala M (2013). Antimicrobial efficacy of endodontic irrigants from Azadirachta indica: An invitro study. Acta Odontologica Scandinavica. 71(6):1594-1598
Fern, K. (2020a. Tropical Plant Database,tropical.the ferns.info.2020-09$03<$ tropical. the ferns.info<view tropical.php

Fern, K. (2020b). Tropical Plant Database, tropical. the ferns.info.2020-09-04< tropical. the ferns.info<view tropical.php

Gomez, K.A. and Gomez, A.A. (1984). Statistical procedure for Agricultural Research. John Wileuy and Sons. New York. pp. 680.

Kalane, V.J. and Chavan, R.T., Kalane, V.J. and Deshmkuh, V.L. (2011). Antimicrobial activity of Cassia tora. Curr. Bot., 2(1):8-9.

Khan, KH. 2009. Role of Emblica officinalis in medicine-A review. Botany Res. Internat. 2(4):218-228.

Kalane, V.J. and Chavan, R.T. , Kalane ,V.J. and Deshmkuh, V.L. (2011). Antimicrobial activity of Cassia tora. Curr.Bot., 2(1):8-9.

Kumar N and Khurana SM. Phytochemistry and medicinal potential of the Terminalia bellirica. Indian J. Natural Products Resources. 9(2): 97-107

Lacobellis NS, Cantore PL, Capasso F, Senatore F 2005. Antibacterial activity of Cuminum cyminum $\mathrm{L}$ and Carum carvi L. Essential oils. J.Agric.Food Chem. 53(1):57-61.

Mali RG (2010). A review on ethnobotany, phytochemistry and pharmacology. Pharmaceutical Biol. 48(1):105-112.

Maity, T.K., Mandal, S.C., Mulkherjee, P, Saha., B.P., Das, J., Pal, M and Saha, B.P. (1998). Studies on anti-inflamatory effect of Cassia leaf extract. Phytother. Res., 12(3); 221-223.

Malekzadeh, F, Ehsanifar, H, Shahamat, M, Levin M, Colwell R.R. 2001. Antibacterial activity of black myrobalan (Terminalia chebula against Helicobacter pylori. Int. J.A ntimicrob Agents. 18:85-88.

Mnif S and Aifa S. 2015. Cumin (Cuminum 
cyminum L.) from traditional uses to potential biomedical applications. Chem. Biodivers. 12(5):733-42.

Negi JS, Bisht VK. Bhandaria AK., Bisht DS. 2014. Quantification of reserpine content and antibacterial activity of Rauolfia serpentina (L) Benth. ex Kurz. African J. Microbiol. Res. 8(2):162-166.

Newman DJ, Cragg GM and Snader KM (2000). The influence of natural products upon drug discovery; Nat. Products Reports. 17: 215-234.

Nunej L.and Aqino, M.D., (2012). Microbici dal activity of clove essential oil.Braz, J.Microbiol. 43(4):255-260.

Parihar, L., Sharma, L., Kapoor, P., Parihar, P. (2012). Detection of antioxidant Immunomodulatory and antimicrobial activity of Amomum aromaticum against Klebsiella pneumoniae. J.Pharm Res. 5(2):901-905.

Perumal Samy, R, Ignacimuthu and Patric Raja, D. (1999). Preliminary screening of ethnomedicinal plants from India. $J$ Ethnofarmacol., 66(2); 235-240.

Ponnusamy, K., Ramadevi, S.R. and Hopper, W. (2009). Antibacterial activity of Terminalia chebula Retz. fruit extract. African J. Microbiol. Res. 3(4):180-184.

Raja Ratna Reddy Y, Krishna Kumari C, Lokanatha O, Mamatha S, Damodar Reddy C. (2016). Antimicrobial activity of Azadirachta indica (neem) leaf ,bark and seed extracts. Int. J. Res. Phytochem. Phrmacol. 3(1):1-4.

Rathre MA, Qureshi M (2016). Foeniculum vulgare: A comprehensive review of its traditional use, phytochemistry, pharmacology and safety. Arabian $J$. Chemistry. 9(2):51574-51583

Saeed S and Tariq P. (2007). Antimicrobial activities of Emblica officinalis and Coriandrum sativum against gram positive bacteria and Candida albicans. Pak J. Bot. 39(3): 913-917.

Sharma, S. K, Perianayagam BJ, Joseph A, Christina AJM. 2003. Antiinflamatory activity of ethanol an aqueous extracts of Emblica officinalis Gearth fruits. Hamdard Medicus. 46:75-78.

Somani AK and Shekhawat GS (1990). Bacterial soft rot of potato in India. Technical Bulletin. 21.CPRI, Shimla. Pp: 32.

Waheed, A., Miana G.A. Ahmad SI,Khan MA 2006. Clinical investigation of hypoglycemic effect of Coriandrum sativum in type-2 (NIDDM) diabetic patients. Pakistan J. Pharmacol. 23(1):711.

Valgas C, Souza SM, Smania EFA,Smania A.2007. Screening methods to determine antibacterial activity of natural products. Brazilian J. Microbiol.38(2):369-380.

Venugopalan SK and Visweswaran N.2013. Neem (Azadirachta indica): Prehistory to contemporary medicinal uses to humankind. Asian Pac J Trop Biomed. 3(7): $505-514$

Zou L, Hu Y-Y, Chen WX.2015.Antibacterial mechanism and activities of black pepper chloform extract. J Food Sci Technol. 52(12): 8196-8203

\section{How to cite this article:}

Biswal, G. and Dhal, N. K. 2020. Studies on Bioefficacy of Aqueous Plant Extracts against Pectobacterium carotovorum causing Black Leg and Soft Rot of Potato Int.J.Curr.Microbiol.App.Sci. 9(10): 3263-3270. doi: https://doi.org/10.20546/ijcmas.2020.910.390 